\title{
Activity of Lygus lineolaris (Heteroptera: Miridae) adults monitored around the periphery and inside a commercial vineyard
}

\author{
Dominique FLEURY ${ }^{1}$, Yves MAUfFETTE ${ }^{2}$, Steve METHOT $^{3}$ and Charles VINCENT ${ }^{4}$ \\ ${ }^{1}$ École d'Ingénieurs de Changins, University of Applied Sciences Western Switzerland, Route de Dullier, 1260 Nyon (VD), \\ Switzerland; e-mail: Dominique.Fleury@eichangins.ch \\ ${ }^{2}$ Département des Sciences Biologiques (Institut des Sciences de l'Environnement), Université du Québec à Montréal, \\ Case Postale 8888, Succursale Centre-Ville Montréal (Qc), H3C 3P8, Canada \\ ${ }^{3}$ Dairy and Swine Research and Development Centre, Agriculture and Agri-Food Canada, 200 College Street, P.O. Box 90, \\ Sherbrooke (Qc), J1M 1Z3, Canada \\ ${ }^{4}$ Horticultural Research and Development Center, Agriculture and Agri-Food Canada, 430 Gouin Blvd, \\ Saint-Jean-sur-Richelieu (Qc), J3B 3E6, Canada
}

Key words. Miridae, Lygus lineolaris, tarnished plant bug, population, phenological stage of grapevine, vineyards and plant-insect relationship, inside vs. periphery abundance

\begin{abstract}
The tarnished plant bug, Lygus lineolaris (Heteroptera: Miridae), is a highly polyphagous pest that feeds on a broad range of economically important crops in North America. Flying L. lineolaris adults can move from crop to crop rapidly and easily. Little is known about the movement of L. lineolaris in or near vineyards. From May to October 2002 and 2003, 39 white sticky traps were positioned inside and at the periphery of a vineyard to study the movements of tarnished plant bug adults. Tarnished plant bug captures were most numerous from the end of July to mid August, with captures of ca. 3000 individuals in one week. During the vegetative season, most individuals were captured flying in and around the vineyard at a height of between 40 and $60 \mathrm{~cm}$. The frequency with which the weeds were mown affected the numbers of adults captured. At the periphery of the vineyard, tarnished plant bug was more abundant near perennial vegetation, which tends to be stable (an apple orchard, a spruce wood), than in the vineyard where agronomic activities changed the availability of food. The tarnished plant bug adults did not hibernate in the vineyard. It is suggested that appropriate weed management will reduce the abundance of tarnished plant bugs in vineyards as it would deprive them of a number of suitable hosts for feeding and oviposition.
\end{abstract}

\section{INTRODUCTION}

The economy of the Canadian wine industry has grown remarkably since the early 1990 s as a result of successfully developing premium quality wines and grapes (CGWRS, 2007). The tarnished plant bug, Lygus lineolaris (Palisot de Beauvois) (Heteroptera: Miridae), which is distributed from Mexico to Alaska (Kelton, 1975) and feeds on at least 398 host plants in North America, including some 130 crops of economic importance, among which are grapes (Young, 1986; Esquivel \& Mowery, 2007). As it is a polyphagous pest, its population dynamics can be affected by the spatial distribution of host plants in an agroecosystem (Rhainds \& EnglishLoeb, 2003). Most of the host plants are broad-leaved dicotyledonous plants, including many weed species (Hardman et al., 2004). As L. lineolaris adults are able to fly more than $12 \mathrm{~km}$ in $12 \mathrm{~h}$ at a speed of $0.45 \mathrm{~m} \mathrm{~s}^{-1}$ (Stewart \& Gaylor, 1994) or $5.12 \mathrm{~km}$ without interruption (MacCreary, 1965), crop to crop movements are likely to happen at larger scales (i.e. agroecosystems).

In diverse agroecosystems (spatially structured landscapes), the distribution of food resources can explain local movements of populations of herbivorous insects (Hunter, 2002). Agroecosystems contain a shifting mosaic of food resources that vary through time in their availability and suitability for pest species (Kennedy \& Storer, 2000; Shelton \& Badenes-Perez, 2006). Field boundaries link movements and dynamics, allowing insects that fly in and out of agroecosystem to access different resources (Bommarco \& Fagan, 2002). Field boundaries or edge effects can result in increases or decreases in insect abundance in agrarian landscapes (Le Coeur et al., 2002). Lygus lineolaris is significantly more abundant in fields that interface with other crops or natural ecosystems (Outward et al., 2008). In an agroecosystem consisting of several species of plants, flying insects are able to choose between food resources and detect gradual changes between plant types, which increase the probability of their crossing from one patch into another (Bommarco \& Fagan, 2002).

In agroecosystems that differ in the availability of food, L. lineolaris adults move easily between crops (Khattat \& Stewart, 1980). For example, they often move from alfalfa to canola (Timlick et al., 1993) or oil seed rape (Butts \& Lamb, 1991) within a season. In southern Quebec, this pest is successively observed on natural vegetation like white clover (Trifolium pratense) early in the season and goldenrod (Solidago canadensis) late in the season (Boivin \& Stewart, 1983). In early spring, overwintered adults move into apple orchards from adjacent woodlands or weedy areas and feed on developing leaves, 


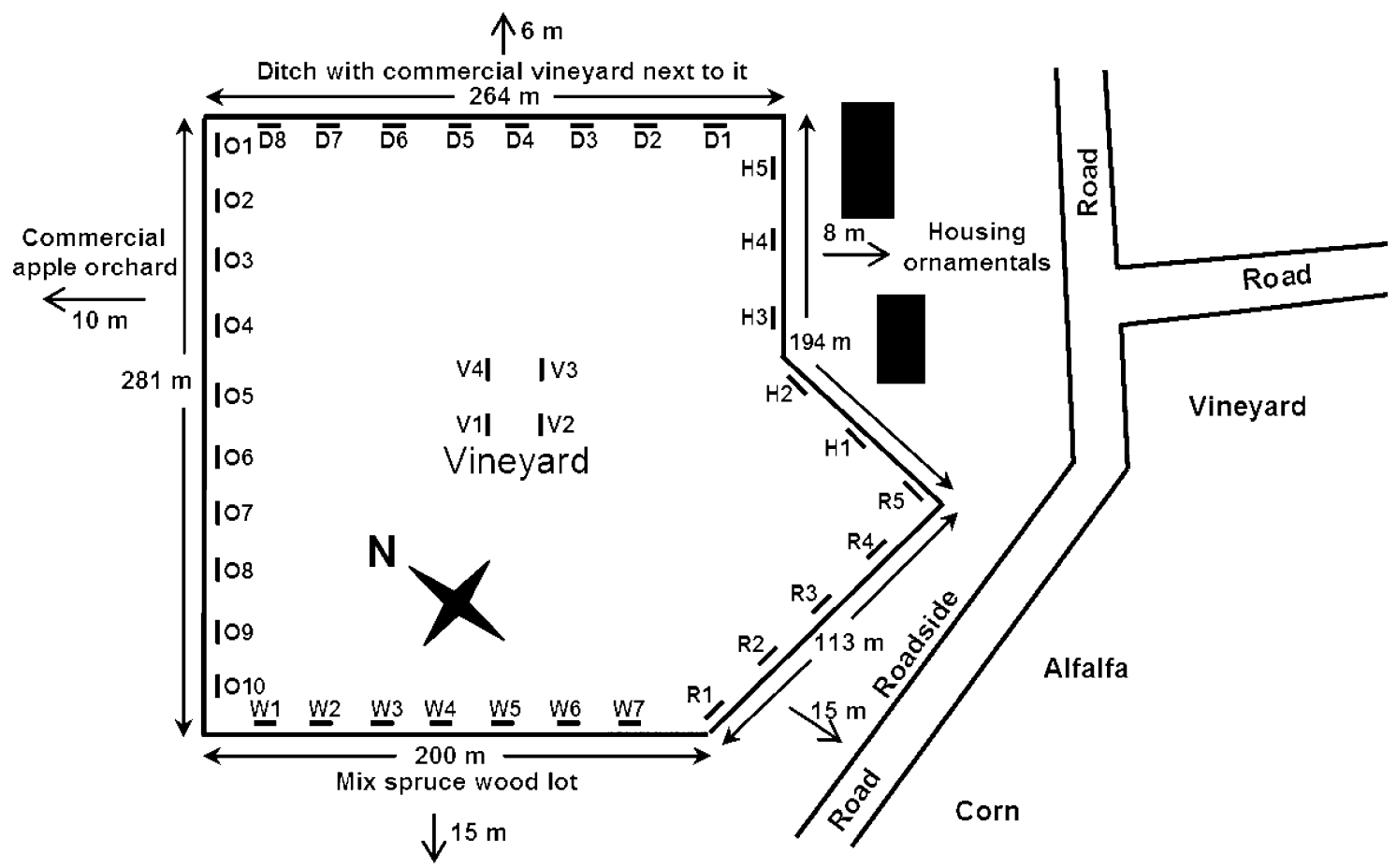

Fig. 1. The commercial vineyard L'Orpailleur (Dunham, Qc, Canada) and surrounding habitats. Traps are represented by bars (small lines) flanked with letters as follows: $\mathrm{O}$ - commercial apple orchard, $\mathrm{D}$ - ditch running alongside the vineyard, $\mathrm{H}$ - ornamentals growing around vineyard buildings, $\mathrm{R}$ - roadside, $\mathrm{W}$ - mixed spruce wood and $\mathrm{V}$ - inside vineyard

flower buds and fruitlets under $1 \mathrm{~cm}$ in diameter (Prokopy et al., 1979; Boivin et al., 1982). Adults then migrate to weeds in adjacent agroecosystems (Hammer, 1939) or feed on the young and meristematic tissues of crops like grapevines (Vitis vinifera).

On the Niagara Peninsula (Ontario, Canada), L. lineolaris nymphs are more abundant on peach trees located at the periphery of orchards (Pree, 1985). In Fredonia (New York, USA), nymphs of two mirids (Taedia scrupeus and Lygocoris inconspicuous) are reported as more abundant at the edge of commercial vineyards (Rhainds et al., 2002). In August in Pennsylvania L. lineolaris is the most abundant mirid in vineyards (Jubb et al., 1979). In a commercial vineyard located in southwestern Quebec, $L$. lineolaris were captured throughout the growing season in pitfall and window traps, and by beating (Bostanian et al., 2003).

In this article, immigration and emigration of $L$. lineolaris adults at the periphery of a commercial vineyard located in a diverse agroecosystem made up of several habitats (i.e. apple orchard, commercial vineyard, a mixed spruce wood and alfalfa), was investigated in order to determine whether they were more abundant inside the vineyard than at the edge. In addition, the effect of weed management, canopy height of $V$. vinifera and weather on the numbers of $L$. lineolaris captured was evaluated.

\section{MATERIAL AND METHODS}

\section{Habitat}

This two year study was conducted at L'Orpailleur, a commercial vineyard located at Dunham $\left(45^{\circ} 06^{\prime} \mathrm{N}, 72^{\circ} 51^{\prime} \mathrm{W}\right)$, Quebec, Canada (Fig. 1). Two grape cultivars were cultivated in the vineyard, Seyval $(80 \%)$ and Marechal-Foch $(20 \%)$, and the vineyard was located in a mosaic consisting of farmland dispersed among natural habitats. There were five habitats adjacent to the vineyard: a mixed spruce wood (south), a ditch $6 \mathrm{~m}$ wide (north), vineyard buildings with ornamental plants (east), an apple orchard (west) and a roadside (east) (Fig. 1). At the periphery of the vineyard, the habitats were separated from the vineyard by a strip of vegetation (from 6 to $15 \mathrm{~m}$ wide). The plant species in the vineyard, the vegetation strips and the roadside were noted each week when the numbers of $L$. lineolaris captured were recorded.

\section{Commercial practices}

The vineyard was managed using standard commercial practices. For winter protection, the growers covered the rootstocks with 30 to $40 \mathrm{~cm}$ of soil in autumn, which was removed in spring. In 2002 and 2003, the vegetation around the vineyard was mowed every two and six weeks, respectively. To control fungal diseases, fungicides [captan (Captan $50 \mathrm{WP}$ ); folpet (Folpan 50 WP); kresoxym-methyl (Sovran); o-ethyl phosphonate (Ridomyl); mancozeb / dinocap (Dikar); metiram (Polyram $80 \mathrm{WP}$ ); myclobutanil (Nova $40 \mathrm{WP}$ )] were applied. To control weeds, herbicides [diuron (Karmex 80W); simazine (Simadex)] were applied to the bases of the rootstocks in each row and the soil between rows raked every month. To control leafhoppers, cyhalothrin-lambda (Matador 120EC) was applied on June $10^{\text {th }}$ in 2002 and July $1^{\text {st }}$ in 2003 . These pesticides were sprayed at the rates recommended in Canada.

\section{Experimental design and trapping of $L$. lineolaris}

Thirty nine white sticky traps were set up, 35 at the periphery and 4 inside the vineyard (Fig. 1) in 2002 and 2003. The length of the perimeter of the vineyard was $1051 \mathrm{~m}$ and the traps were spaced at intervals of $30 \mathrm{~m}$, enclosing an area of ca. $7.5 \mathrm{ha}$. The traps were $30 \mathrm{~cm}$ in width and were covered with glue from 20 $\mathrm{cm}$ up to $140 \mathrm{~cm}$ above the ground. The traps had two sticky 

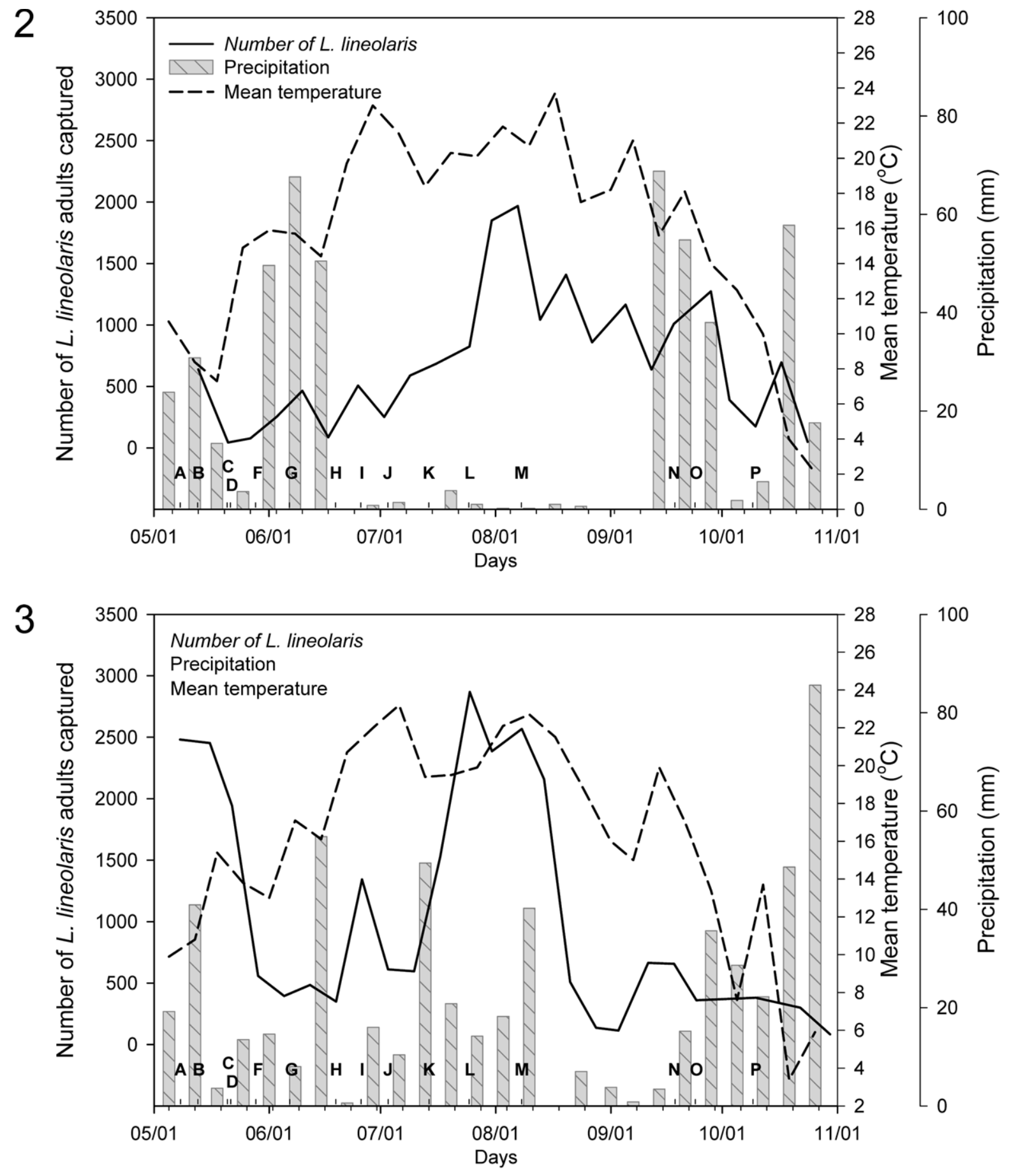

Figs 2, 3: Seasonal trends in the numbers of adults of L. lineolaris caught in a commercial vineyard (pooled data for the 39 white traps), mean temperature and precipitation in 2002 (2) and 2003 (3). Letters indicate phenological stages of the grapevine based on Baillod \& Baggiolini (1993).

surfaces, one facing into the vineyard (inner side) and the other facing one of the five neighbouring habitats (outer side). The numbers of $L$. lineolaris caught by the traps and the phenological stages of the grapevines were recorded weekly from May to October in both years. Lygus lineolaris adults were removed every week from the traps. The Tangle-trap ${ }^{\circ}$ coating on the surface of the traps was refreshed monthly. The total number of insects captured was calculated for each phenological stage of $V$. vinifera.

The phenological stages proposed for $V$. vinifera by Baillod \& Baggiolini (1993) were used: winter bud (phenological stage A), bud burst (B), green tip (C), emerging leaves (D), first flat leaves $(E)$, visible cluster $(F)$, separated cluster $(G)$, florets separated $(\mathrm{H})$, flowering $(\mathrm{I})$, berry set $(\mathrm{J})$, pea size $(\mathrm{K})$, cluster closure-berry touch $(\mathrm{L})$, veraison $(\mathrm{M})$, maturity $(\mathrm{N})$, senescence (O) and leaf fall (P). When the alfalfa crop was cut and the apple phenological stages were also noted. Weather data (i.e. temperature, rainfall) was recorded at the Research Station of Agriculture and Agri-Food Canada in Frelighsburg, Qc, located ca. $3 \mathrm{~km}$ from L'Orpailleur vineyard. 
TABLE 1. Total captures of L. lineolaris adults on the inner and outer sides of traps at the periphery of a vineyard in 2002 and 2003 (data for traps at the center of the vineyard not shown).

\begin{tabular}{|c|c|c|c|c|c|}
\hline \multirow{2}{*}{ Habitats } & \multirow{2}{*}{$\begin{array}{l}\text { Number } \\
\text { of traps }\end{array}$} & \multicolumn{2}{|c|}{2002} & \multicolumn{2}{|c|}{2003} \\
\hline & & Inner & Outer & Inner & Outer \\
\hline Wood lot (with mix spurs) & 7 & $2061 * *$ & 1287 & $2679 * *$ & 1877 \\
\hline Ditch (with a vineyard next to it) & 8 & $830 * *$ & 1610 & $2674 *$ & 2848 \\
\hline Housing (with ornamentals around) & 5 & $1170 * *$ & 935 & $1521 * *$ & 2201 \\
\hline Roadside (with alfalfa next to it) & 5 & $945 * *$ & 467 & 1167 & 1154 \\
\hline Apple orchard & 10 & $1823 * *$ & 4046 & 3642 & 3799 \\
\hline
\end{tabular}

Inner - trapping surface facing inside the vineyard; Outer - trapping surface facing outside the vineyard (ex. habitats zone described). ${ }^{*}-\chi^{2}$ significant at $\mathrm{P}=0.05, * *-\chi^{2}$ significant at $\mathrm{P}=0.01$.

\section{Overwintering experiment}

During November 2002 and 2003, soil was removed from the bases of 15 Seyval rootstocks in order to establish overwintering sites for L. lineolaris adults in the vineyard. In late November, these vine plants were wrapped in a sleeve-cage in order to determine whether $L$. lineolaris adults overwintered in the vineyard and moved out in the spring. The 15 rootstocks were located near the apple orchard and the wood. The control vine plants, of which the rootstocks were covered in soil, were also wrapped in a sleeve-cage.

\section{Data analysis}

Captures of $L$. lineolaris adults were mostly resumed by descriptive statistics. For each year, differences among habitats were detected using a weighted one-way analysis of variance (ANOVA) with pair-wise comparisons adjusted using Tukey's test for multiple comparisons. Height of flight of the bugs was expressed in terms of percentages caught on each section of the traps. All analyses were conducted using SAS software (SAS, 2000).

\section{RESULTS}

Although more L. lineolaris were captured in 2003 (26186) than in 2002 (17109), the seasonal pattern in the numbers captured were similar (Figs 2 and 3), except for the first week of trapping when 639 individuals were captured on May $13^{\text {th }} 2002$ in contrast to 2481 on May $8^{\text {th }}$ 2003. Slightly higher activities at phenological stages J in 2002 and I in 2003 were also recorded (Figs 2 and 3). A great number were captured during phenological stages $\mathrm{A}, \mathrm{B}$ and $\mathrm{D}$ in 2003. The highest number captured in one week was recorded at phenological stage L: 1969 (early August) and 2868 (end of July) in 2002 and 2003, respectively. The largest number captured was recorded at phenological stage $\mathrm{M}$.

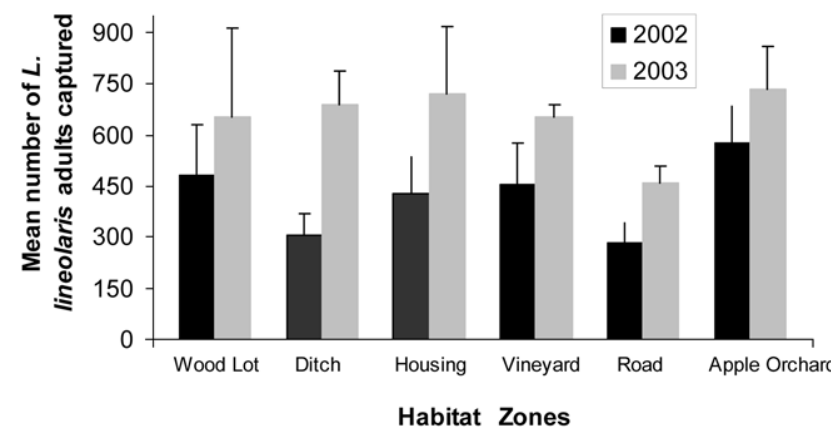

Fig. 4. Mean number of adults of $L$. lineolaris caught in each of the habitats adjacent to the vineyard in 2002 and 2003.
In 2002 , the cumulative captures per habitat were significantly different between inner and outer sides of traps. In 2003 the numbers captured in the wood, around the buildings and ditch differ significantly (Table 1). These captures indicate that the numbers present in the wood and at the orchard edges of the vineyard were similar in both years (Fig. 5 A-B and E-F). For example, arround the vineyard, the captures by all traps totalled 6829 and 8345 for the inner and outer sides in 2002, compared to 11683 and 11879 in 2003. Therefore, the captures of inner and outer sides of each trap were pooled to reflect the global activity of a specific trap in a given habitat (i.e. apple orchard).

There were significant differences in the average captures of L. lineolaris adults in the different habitats and years. For example, in both years, a separate analysis showed that captures were significantly higher near the orchard than near the roadside (Table 2). In 2002, captures were significantly higher near the wood than along the ditch and the roadside; and captures were significantly higher near the orchard than along the roadside (Table 2). The ten sticky traps along the edge of the orchard (Fig. 5 C-D), recorded a decrease of $78 \%$ (from 622 to 131) in the number of adults captured between May $22^{\text {nd }}$ and $29^{\text {th }}$ in 2003. In 2002, trap O 10 (Fig. 1) caught the greatest

TABLE 2. Probability resulting from statistical comparison of average captures between habitats, in 2002 and 2003 (both side of traps pooled).

\begin{tabular}{lcc}
\hline Comparison of habitats & 2002 & 2003 \\
\hline Vineyard vs Wood lot & 0.9988 & 1.0000 \\
Vineyard vs Orchard & 0.3889 & 0.9534 \\
Vineyard vs Ditch & 0.2168 & 0.9989 \\
Vineyard vs Housing & 0.9986 & 0.9881 \\
Vineyard vs Roadside & 0.1750 & 0.4453 \\
Wood lot vs Orchard & 0.4457 & 0.8861 \\
Wood lot vs Ditch & $0.0325^{*}$ & 0.9962 \\
Wood lot vs Housing & 0.9522 & 0.9725 \\
Wood lot vs Roadside & $0.0331^{*}$ & 0.3184 \\
Ditch vs Orchard & $<0.0001^{*}$ & 0.9913 \\
Ditch vs Housing & 0.3518 & 0.9994 \\
Ditch vs Roadside & 0.9990 & 0.1285 \\
Housing vs Orchard & 0.1271 & 1.0000 \\
Housing vs Roadside & 0.2830 & 0.1171 \\
Roadside vs Orchard & $0.0002^{*}$ & $0.0328^{*}$ \\
\hline
\end{tabular}

* - Significant differences at $\mathrm{P}=0.05$ (ANOVA + Tukey comparison). 

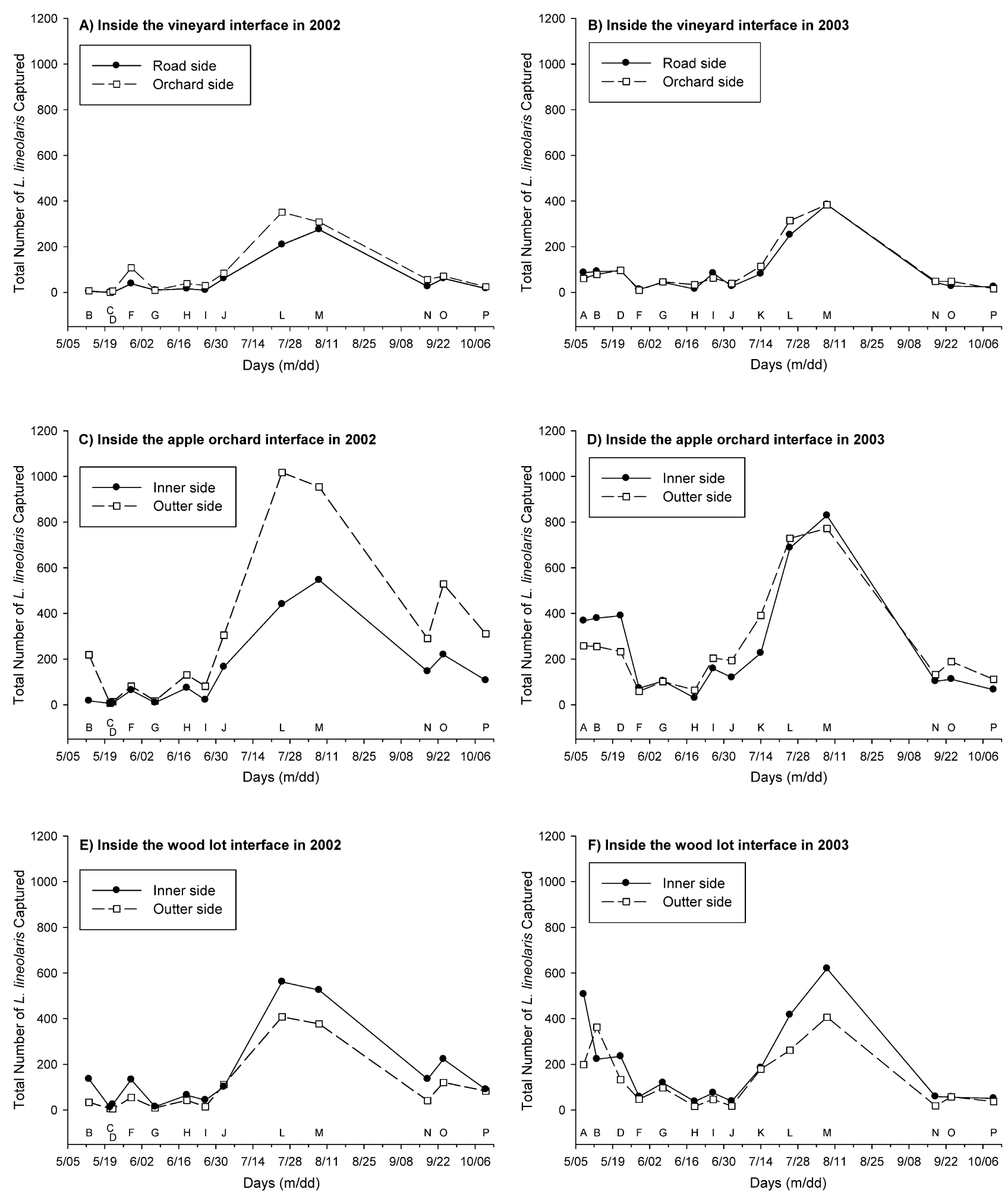

Fig. 5. Seasonal trends in numbers of adults of $L$. lineolaris caught on the inner and outer facing sides of traps placed in the vineyard: $\mathrm{A}+\mathrm{B}=$ in the centre of the vineyard in 2002 and 2003; C $+\mathrm{D}=$ along the edge adjacent to the apple orchard in 2002 and 2003; E + F = along the edge adjacent to the wood in 2002 and 2003. Capital letters on the horizontal axis refer to phenological stages of the grapevine based on Baillod \& Baggiolini (1993).

number (789) of adults and in 2003, the second greatest number (1009).

For all the phenological stages of $V$. vinifera pooled, most individuals were captured at heights of 40 and 60 $\mathrm{cm}$ (Fig. 6). The height of flight of L. lineolaris adults significantly differed among phenological stages of $V$. vinifera. A mean flight height $>80 \mathrm{~cm}$ was recorded at phenological stages A to $\mathrm{L}$ and of $<80 \mathrm{~cm}$ at the late phenological stages $\mathrm{M}$ to $\mathrm{P}$. 


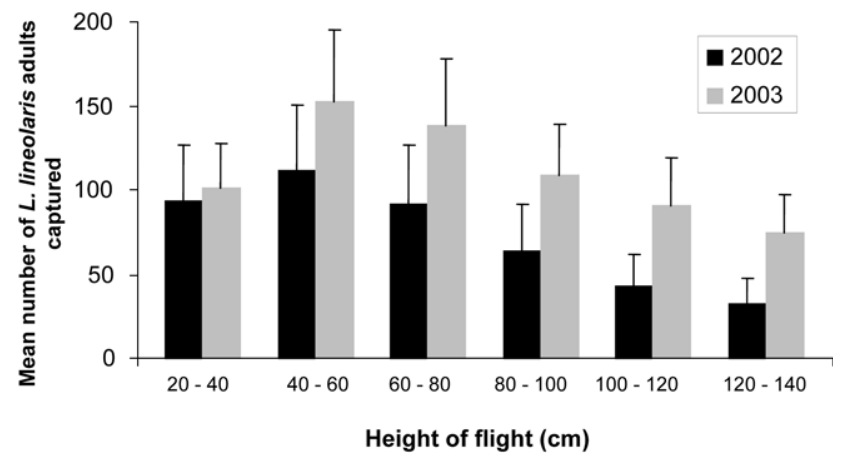

Fig. 6. Mean number of adults of $L$. lineolaris caught at different heights in 2002 and 2003.

Along the roadside and in the vegetation strip bordering the vineyard, dandelion (Taraxacum officinale), rayless camomile (Matricaria matricarioides), white clover (Trifolium repens), red clover (T. pratense), ox-eye daisy (Chrysanthemum leucanthemum), cow vetch (Vicia cracca), yellow water-crowfoot (Ranunculus flabellaris), aster (Aster spp.) and goldenrod (Solidago canadensis), were recorded. In the vineyard, the main weeds were common plantain (Plantago major), red-root pigweed (Amaranthus retroflexus), purslane (Portulaca oleracea), barnyard-grass (Echinochloa crus-galli) and common milkweed (Asclepias incarnata). All these plants are potential hosts of L. lineolaris (Young, 1986).

No L. lineolaris adults emerged in spring in the sleevecages positioned late the previous autumn around Seyval Blanc rootstocks that were not covered with soil. The same result was observed when the rootstocks were covered with soil.

\section{DISCUSSION}

The number of adult L. lineolaris in L'Orpailleur vineyard differed in the two years. Variation in the abundance of $L$. lineolaris in other crops is documented. In Iowa the peak numbers of $L$. lineolaris recorded in alfalfa and strawberry fields in 2001 were approximately 2.5 times those recorded in 2000 (Bethzayda \& Obrycki, 2004). It is likely that abiotic conditions (i.e. rain, temperature) affected the number of $L$. lineolaris adults captured (Wold \& Hutchison, 2003). During May-June, high rainfall (165 to $272 \mathrm{~mm}$ ) reduced the numbers of first generation nymphs of $L$. lineolaris in alfalfa by $50 \%$ (Day, 2006). In contrast, adults continued to fly, probably because the rainfalls were lower: from 83.2 to $127.8 \mathrm{~mm}$ (Figs 2 and 3). At the end of October, the number of bugs decreased because the temperature dropped and $V$. vinifera shed its leaves (Figs 2 and 3). There was no correlation between wind direction and the numbers of $L$. lineolaris caught on the inner and outer surfaces of the traps.

In both years, peak captures of $L$. lineolaris adults coincided with the vine phenological stages $\mathrm{M}$ and L. Phenological stage $M$ lasted for six weeks (i.e. longer than any other phenological stage). In terms of weekly captures $L$. lineolaris was most abundant at phenological stage L, which lasted from the end of July to early August, as Jubb et al. (1979) reported for Pennsylvania vineyards. Fleury et al. (2006) report that the adults spend more time feeding at phenological stage $\mathrm{L}$ than any other stage, except $\mathrm{H}$. The preference of adults for feeding on the pedicels of young berries possibly explains why adults were more numerous during this period of the year in the vineyard. The peak in early October 2002 suggests there is a third generation in southern Quebec. This may be because $V$. vinifera flowers throughout the growing season and so provides a valuable source of food for not only the first generation adults of $L$. lineolaris but also the second and the third generations that feed on earlymaturing weed species late in the season.

When apple orchards are in full bloom they are an attractive food source to overwintered flying adults (Prokopy et al., 1979). This suggests that L. lineolaris adults stayed inside the orchard instead of searching for food in the nearby vineyard. In mid-June, apples were 1 $\mathrm{cm}$ in diameter and the activity of L. lineolaris adults at the edge of the orchard decreased. After flowering, when there was less meristematic tissue (except for a few suckers) in the orchard, adults dispersed to feed upon young and tender hosts elsewhere in the agroecosystem.

Blackmer et al. (2008) captured the highest numbers of L. lineolaris on traps located in a cleared area between two alfalfa fields and lowest numbers at the edge and in the center of the fields. In the vineyard, the sizes of the captures of the traps inside and at the periphery of the vineyard were overall similar (Fig. 4). There are three possible reasons for this: (a) the traps were white, like the flowers of $V$. vinifera, and thus closely mimicked the flowers in the vineyard; (b) the traps extended from 20 $\mathrm{cm}$ above the ground up to $140 \mathrm{~cm}$, which corresponded with the within canopy, canopy and above canopy levels of the $V$. vinifera; (c) for several insect species, host plants surrounded by bare ground are more visually apparent and consequently receive more visits (Smith, 1976).

In general, insect dispersal is lower in less disturbed habitats (low management) because there is more food for insects in such habitats (St Pierre et al., 2005). For example, L. lineolaris populations increase when there is a shift from conventional cultivation to conservation tillage (Byers et al., 1999; Tillman et al., 2004).

As reported by Prokopy et al. (1979) for apple orchards and Rancourt et al. (2000) for strawberry crop, the adults of L. lineolaris flew at between 40 and $100 \mathrm{~cm}$ above the ground in the vineyard. In the present study, most of the L. lineolaris adults were captured flying between these heights. This means that adults fly at the same height in most cultivated fruit crops. Also, in order to catch the maximum number of adults the traps should extend from 40 to $100 \mathrm{~cm}$ above the ground.

In 2002, the more frequent mowing decreased the weed population in and around the vineyard, which might explain the difference in the total captures in 2002 and 2003. Several authors report that L. lineolaris is more abundant on weeds than crops (Boivin et al., 1981; Fleischer \& Gaylor, 1988) and frequently feed on both, crops and weeds (Norris \& Kogan, 2000). Weeds are a 
valuable source of food for L. lineolaris because with fertilisation they grow rapidly and provide a suitable food source (Marshall \& Moonen, 2002). As L. lineolaris adults can easily fly between habitats, the management of weeds has been used to reduce the abundance of this bug in peach orchards in North Carolina (Killian \& Meyer, 1984) and New Jersey (Atanassov et al., 2002), cotton in the southern US (Womack \& Schuster, 1987, Snodgrass et al., 2000) and alfalfa in Washington (Fye, 1980). At L'Orpailleur, there were weeds in the field boundaries, which could have acted as refuges for over-wintering. This could be an important factor influencing arthropod abundance, especially as insects disperse at the end of the vegetative season (Maudsley et al., 2002). As weeds are used by L. lineolaris for food as well as reproduction (Snodgrass et al., 2006), a valuable control strategy could be the mowing of strips to encourage the continuous production of attractive food along the roadside and in the ditch. This would reduce the quantity of food suitable for the reproduction of $L$. lineolaris but provide enough to prevent them feeding on $V$. vinifera. Thus, even though $V$. vinifera continuously produced meristems, the high population of adults captured in 2003 may have been due to the presence of more weeds in the L'Orpailleur vineyard in that year.

In the laboratory adults of $L$. lineolaris feed on all phenological stages of $V$. vinifera (Fleury et al., 2006). In the vineyard adults were present early in the year and throughout the growing season. So, L. lineolaris could remain in vineyards feeding on the continuously growing $V$. vinifera throughout the vegetative season.

Results of the overwintering experiment indicate that L'Orpailleur is not a suitable overwintering habitat for $L$. lineolaris adults, since no adults emerged from the soil (debris) or other host plants sampled in the vineyard. This suggests that $L$. lineolaris adults either overwintered in an adjacent habitat (i.e. the wood) or remained in the vineyard where they died because of the very harsh winter conditions experienced there. The captures in late October indicate that $L$. lineolaris adults flew from the interior to the periphery of the vineyard and did not remain on $V$. vinifera after it shed its leaves.

In vineyards, $V$. vinifera may be an attractive source of food, from spring to autumn, for $L$. lineolaris adults. Even though L. lineolaris is highly polyphagous it prefers meristems and feeds mostly on young apples and weeds. In the context of Integrated Pest Management the application of herbicides or the mowing of weeds should reduce the number of L. lineolaris during the vegetative season, and in or at the periphery vineyards located in diverse agroecosystems sticky traps should be placed at a height of below $1 \mathrm{~m}$ in order to monitor the numbers of $L$. lineolaris adults.

ACKNOWLEDGEMENTS. The authors thank I. Lavoie, G. Larouche, M. Thibeau, P. Lemoyne, A. Chevalier and P. Rigole for their technical help and M. Tremblay for his infographic skills. This project was financed by matching funds from Agriculture and Agri-Food Canada and L'Orpailleur vineyard (Ch.-H. De Coussergues).

\section{REFERENCES}

Atanassov A., Shearer P.W., Hamilton G. \& Polk D. 2002: Development and implementation of reduced risk peach arthropod management program in New Jersey. J. Econ. Entomol. 95: 803-812.

Baillod M. \& Baggiolini M. 1993: Les stades repères de la vigne. Rev. Suisse Vitic. Arboric. Hortic. 25: 7-9.

Bethzayda M. \& OBRycki J.J. 2004: Abundance and parasitism of Lygus lineolaris in alfalfa and strawberry fields. J. Kansas Entomol. Soc. 77: 69-79.

Blackmer J.L., Byers J.A. \& Rodriguez-SaOna C. 2008 : Evaluation of color traps for monitoring Lygus spp.: design, placement, height, time of day, and non-target effects. Crop Prot. 27: 171-181.

Boivin G. \& Stewart R.K. 1983: Seasonal development and interplant movement of phytophagous mirids (Hemiptera: Miridae) on alternate host plants in and around an apple orchard. Ann. Entomol. Soc. Am. 76: 776-778.

Boivin G., Mailloux G., Paradis R.O. \& Pilon J.-G. 1981: La punaise terne, Lygus lineolaris (P. de B.) (Hemiptera: Miridae), dans le sud-ouest du Québec: II. Fluctuations saisonnières des populations sur certaines mauvaises herbes. Ann. Soc. Entomol. Qc 26: 159-169.

Boivin G., Stewart R.K. \& Rivard I. 1982: Sticky traps for monitoring phytophagous mirids (Hemiptera: Miridae) in an apple orchard in southwestern Quebec. Environ. Entomol. 11: 1067-1070.

Bommarco R. \& Fagan F.F. 2002: Influence of crop edges on movement of generalist predators: a diffusion approach. Agric. Forest Entomol. 4: 21-30.

Bostanian N.J., Vincent C., Goulet H., Lesage L., Lasnier J., Bellemare J. \& Mauffette Y. 2003: The arthropod fauna of Quebec vineyards with particular reference to phytophagous arthropods. J. Econ. Entomol. 96: 1221-1229.

ButTs R.A. \& LAmB R.J. 1991: Seasonal abundance of three Lygus species (Heteroptera: Miridae) in oilseed rape and alfalfa in Alberta. J. Econ. Entomol. 84: 450-456.

Byers R.A., Bahler C.C., Strout W.L., Leath K.T. \& Hoffman L.D. 1999: The establishment of alfalfa into different maize residues by conservation-tillage and its effect on insect infestation. Grass Forage Sci. 54: 77-86.

Canadian Grape and Wine Research Strategy (CGWRS) 2007: Championing a Winning Example for Canadian Agriculture. $34 \mathrm{pp}$.

DAY W.H. 2006: The effect of rainfall on the abundance of tarnished plant bug nymphs [Lygus lineolaris (Palisot)] in alfalfa fields. Trans. Am. Entomol. Soc. 132: 445-450.

Esquivel J.F. \& Mowery S.V. 2007: Host plants of the tarnished plant bug (Heteroptera: Miridae) in central Texas. Environ. Entomol. 36: 725-730.

FLEISCHER S.J. \& GAYLOR M.J. 1988: Lygus lineolaris (Heteroptera: Miridae) population dynamics: nymphal development, life tables, and Leslie matrices on selected weeds and cotton. Environ. Entomol. 17: 246-253.

Fleury D., Paré J., Vincent C. \& Mauffette Y. 2006: Feeding impact of the tarnished plant bug Lygus lineolaris (Heteroptera: Miridae) on grapevine: a behavioural and histological study. Can. J. Bot. 84: 493-500.

FyE R.E. 1980: Weed sources of Lygus bugs in the Yakima Valley and Columbia basin in Washington. J. Econ. Entomol. 73: 469-473.

Hammer O.H. 1939: The tarnished plant bug as an apple pest. $J$. Econ. Entomol. 39: 259-264.

Hardman J.M., Jensen K.I.N., Moreau D.L., Franklin J.L. \& BENT E.D. 2004: Effects of ground cover treatments and 
insecticides use on population density and damage caused by Lygus lineolaris (Heteroptera: Miridae) in apple orchards. $J$. Econ. Entomol. 97: 993-1002.

HunTER M.D. 2002: Landscape structure, habitat fragmentation, and the ecology of insects. Agric. Forest Entomol. 4: $159-166$.

JubB G.L. JR., Masteller E.C. \& Wheeler A.G. JR. 1979: Survey of arthropods in vineyards of Erie County, Pennsylvania: Hemiptera: Heteroptera. Environ. Entomol. 8: 982-986.

Khattat R.R. \& Stewart R.K. 1980: Population fluctuations and interplant movements of Lygus lineolaris. Ann. Entomol. Soc. Am. 73: 282-287.

Kelton L.A. 1975: The Lygus Bugs (Genus Lygus Hahn) of North America (Heteroptera: Miridae). Memoirs of the Entomological Society of Canada (\# 95). Published by the Entomological Society of Canada, Ottawa, $89 \mathrm{pp}$.

KenNedy G.G. \& Storer N.P. 2000: Life systems of polyphagous arthropod pests in temporally unstable cropping systems. Annu. Rev. Entomol. 45: 467-493.

KiLLIAN J.C. \& MEYER J.R. 1984: Effect of orchard weed management on catfacing damage to peaches in North Carolina. $J$. Econ. Entomol. 77: 1596-1600.

Le Coeur D., Baudry J., Burel F. \& Thenail C. 2002: Why and how we should study field boundary biodiversity in an agrarian landscape context. Agric. Ecos. Environ. 89: 23-40.

MaCCREARY D. 1965: Flight range observations on Lygus lineolaris and certain other Hemiptera. J. Econ. Entomol. 58: 1004-1005.

Marshall E.J.P. \& Moonen A.C. 2002: Field margins in northern Europe: their functions and interaction with agriculture. Agric. Ecos. Environ. 89: 5-21.

Maudsley M., Seeley B. \& Lewis O. 2002: Spatial distribution patterns of predatory arthropods within an English hedgerow in early winter in relation to habitat variables. Agric. Ecos. Environ. 89: 77-89.

NorRis R.F. \& Kogan M. 2000: Interactions between weeds, arthropod pests, and their natural enemies in managed ecosystems. Weed Sci. 48: 94-158.

Outward R., Sorenson C.E. \& Bradley JR J.R. 2008: Effects of vegetated field borders on arthropods in cotton fields in eastern North Carolina. J. Insect Sci. 8: 09.

Pree D.J. 1985: Control of the tarnished plant bug, Lygus lineolaris (Palisot de Beauvois) on peaches. Can. Entomol. 117: 327-331.

Prokopy R.J., Adams R.G. \& Hauschild K.I. 1979: Visual responses of tarnished plant bug adults on apple. Environ. Entomol. 8: 202-205.

Rancourt B., Vincent C. \& De Olivera D. 2000: Circadian activity of Lygus lineolaris (Hemiptera: Miridae) and effectiveness of sampling techniques in strawberry fields. J. Econ. Entomol. 93: 1160-1166.

Rhainds M. \& English-Loeb G. 2003: Testing the resource concentration hypothesis with tarnished plant bug on strawberry: density of hosts and patch size influence the interaction between abundance of nymphs and incidence of damage. Ecol. Entomol. 28: 348-358.

Rhainds M., Taft T., English-Loeb G., Dunst R. \& Weigle T. 2002: Ecology and economic impact of two plant bugs (Hemiptera: Miridae) in commercial vineyards. J. Econ. Entomol. 95: 354-359.

SAS (Statistical Analysis System) 2000: Release 8.02. SAS Institute Inc., Cary NC.

Shelton A.M. \& Badenes-Perez F.R. 2006: Concepts and applications of trap cropping in pest management. Annu. Rev. Entomol. 51: 285-308.

SмIтн J.G. 1976: Influence of crop background on aphids and other phytophagous insects on brussel sprouts. Ann. Appl. Biol. 83: 1-13.

Snodgrass G.L., Scott W.P., Hardee D.D. \& Robbins J.T. 2000: Results from two years of an experiment on tarnished plant bug control in cotton through reduction in number of early-season wild host plants. In Proceedings: Beltwide Cotton Production Research Conference, Memphis, TN. National Cotton Council of America, Memphis, TN, pp. 1229-1233.

Snodgrass G.L., Scott W.P., Abel C.A., Robbins J.T., Gore J. \& HardeE D.D. 2006: Tarnished plant bug (Heteroptera: Miridae) populations near fields after early season herbicide treatment. Environ. Entomol. 34: 705-711.

Stewart S.D. \& GAYLOR M.J. 1994: Effects of age, sex, and reproductive status on flight by the tarnished plant bug (Heteroptera: Miridae). Environ. Entomol. 23: 80-84.

St Pierre M.J., Hendrix S.D. \& Lewis C.K. 2005: Dispersal ability and host plant characteristics influence spatial population structure of monophagous beetles. Ecol. Entomol. 30: $105-115$.

Tillman G., Schomberg H., Phatak S., Mullinix B., Lachnicht S., Timper P. \& Olson D. 2004: Influence of cover crops on insect pests and predators in conservation tillage cotton. $J$. Econ. Entomol. 97: 1217-1232.

Timlick B.H., Turnock W.J. \& Wise I. 1993: Distribution and abundance of Lygus spp. (Heteroptera: Miridae) on alfalfa and canola in Manitoba. Can. Entomol. 125: 1033-1041.

Wold S.J. \& Hutchison W.D. 2003: Phenology of Lygus lineolaris (Hemiptera: Miridae) in Minnesota June-bearing strawberries: comparison of sampling methods and habitats. $J$. Econ. Entomol. 96: 1814-1820.

WoMACK C.L. \& SCHUSTer M.F. 1987: Host plants of the tarnished plant bug (Heteroptera: Miridae) in the northern blackland prairies of Texas. Environ. Entomol. 16: 1266-1272.

Young O.P. 1986: Host plants of the tarnished plant bug, Lygus lineolaris (Heteroptera: Miridae). Ann. Entomol. Soc. Am. 79: $747-762$.

Received October 1, 2009; revised and accepted April 12, 2010 